\title{
The Implementation of Documentation by Midwives in Pekanbaru
}

\section{Pelaksanaan Dokumentasi oleh Bidan di Pekanbaru}

\author{
Wan Anita
}

\section{Tengku Maharatu School of Health Sciences, Pekanbaru, Indonesia}

\begin{abstract}
Midwifery documentation is a recording and reporting evidence owned by midwives in performing care records that is useful for the interest of patient, midwives and health team. Documenting can be applied to the Subjective, Objective, Analysis and Planning (SOAP) method. This study aimed to determine factors associated with the implementation of the SOAP documentation by midwife in Pekanbaru City in 2016. This study was a quantitative analytical observational study with analytic cross-sectional study design. The population was all Independent Practice of Midwives or maternity hospital in Pekanbaru City with a total sample of 191 midwives with systematic random sampling procedure. Data were collected through interview using questionnaires and the midwives' documentation records. The results showed that variables which affected the implementation of SOAP documenting method were the documentation format (POR 15.988), supervision (POR 6.366) and attitude (POR 2.729). This means that midwives with the unavailable format are 16 times at risk of carrying out the documentation not in accordance with SOAP, while the midwives who are never supervised are 6 times at risk and the midwives with negative attitudes are 3 times at risk.
\end{abstract}

Keywords: Documentation, implementation, midwives

\begin{abstract}
Abstrak
Dokumentasi kebidanan adalah suatu bukti pencatatan dan pelaporan yang dimiliki oleh bidan dalam melakukan catatan perawatan yang berguna untuk kepentingan pasien, bidan, dan tim kesehatan. Pendokumentasian dapat diterapkan dengan metode Subjektif, Objektif, Analisa dan Perencanaan (SOAP). Penelitian ini bertujuan mengetahui faktor-faktor yang berhubungan dengan pelaksanaan dokumentasi SOAP oleh bidan di Kota Pekanbaru tahun 2016. Penelitian bersifat kuantitatif analitik observasional dengan desain penelitian potong lintang analitik. Sampel penelitian adalah seluruh populasi bidan yang praktik mandiri atau di rumah bersalin di Kota Pekanbaru dengan jumlah sampel sebanyak 191 bidan yang diambil dengan prosedur systematic random sampling. Data dikumpulkan melalui wawancara langsung dengan menggunakan kuesioner dan melihat catatan dokumentasi bidan. Hasil penelitian menunjukkan variabel yang berpengaruh terhadap pelaksanaan dokumentasi SOAP adalah format dokumentasi (POR 15,988), supervisi (POR 6,366) dan sikap (POR 2,729). Artinya bidan dengan format yang tidak tersedia berpeluang 16 kali untuk melaksanakan dokumentasi tidak sesuai SOAP, yang tidak pernah disupervisi berisiko enam kali, dan yang bersikap negatif berisiko tiga kali.
\end{abstract}

Kata Kunci: Dokumentasi, pelaksanaan, bidan

How to Cite: Anita W. The implementation of documentation by midwives in Pekanbaru. Kesmas: National Public Health Journal. 2018; 13 (1): 43-47. (doi: 10.21109/kesmas.v13i1.1403)
Correspondence: Wan Anita, Tengku Maharatu School of Health Sciences, Soekarno Hatta Street No.98, Delima, Tampan, Pekanbaru City, Riau Province, Indonesia, Phone: +62761-566820, E-mail: wan_anita77@yahoo.co.id Received: January $11^{\text {th }} 2017$

Revised: March 28th 2018

Accepted: May $11^{\text {th }} 2018$ 


\section{Introduction}

Midwivery documentation is a recording and reporting evidence owned by midwives in performing care records that is useful for the interest of patient, midwives and health team in providing health services to the basic communication that is accurate and complete as responsibly written by midwife. Documenting or recording the obstetric management could be applied the subjective, Objective, Analysis and Planning (SOAP) method. ${ }^{1}$ SOAP method was a simple record, clear, logical, and concise. The principle of the SOAP method was the thought obstetric management process. In the SOAP method, Subjective data are complaints of the patients, objective data are the result of patient's physical exam and other diagnostic laboratory tests. Analysis is statement of the analysis and interpretation (conclusion) of subjective and objective data. Planning is the current and the future management midwife care based on data analysis. $^{2}$

The carelessness of midwives to perform the task is really concerned in documentation of midwifery because the documentation could be used for accusations. Undocumented midwifery care makes the practice unqulified and can be lawsuit in case of malpractice. ${ }^{3}$

The obligation for documenting is stipulated in the Law No. 36 of 2014 on Health Workers. If the health worker does not carry out the provisions of clause number 58 on documentation, administrative sanctions will be applied in the forms of verbal warning, written warning, administrative fines or license revocation. ${ }^{4}$ Other rules of governing midwifery documentation are Decree of Minister of Health No.369/Menkes/SK/III/2007 on Standards of Professional Midwives and Regulation of Minister of Health No.1464/Menkes/PER/X/2010 on the Permissions and Implementation of Midwife practice, and the Regulation of Minister of Health No. 938/Menkes/SK/VIII/2007 on Standards of Midwifery Care. Standard VI states that midwifery care recording is that midwives must take recording completely, accurately, concisely, and clearly about the situation/incident found and carried in providing midwifery care. ${ }^{5-7}$

The results of a study on nursing care documentation completeness and characteristic found that nursing care completeness of documentation reached $63 \%$. The nurse's knowledge of documentation was considered adequate, they had been trained and documentation facilities were adequately provided. ${ }^{8}$ Study on the factors affecting the performance of midwives in the implementation of standard midwifery care for delivery woman's had been undertaken in Semarang district. The most influential factors to the implementation of standard midwifery care for woman's delivery were knowledge, perception of supervision, workload, and sanction. ${ }^{9}$ A study on documents in labor by midwives at the Madonna university teaching hospital Elele rivers state of Nigeria showed that midwives have good knowledge in labor documentation, but have a poor attitude in practice. Influential factors include; time, midwife's attitude, and many midwives working in shifts. ${ }^{10}$

Data by Indonesian Midwives Association in Pekanbaru City indicate that there are 247 midwives who practice independently. As a condition of obtaining a license recommendation to open the independent practice or renewal of a license, the association has provided examples of SOAP documentation formats to be used later during midwifery care provided. However, there are none data of midwives that carry out documentation of SOAP for the association in Pekanbaru. At present, SOAP documentation among the independent practice midwives has not been monitored regularly yet. ${ }^{11}$ Preliminary survey which was conducted on 30 midwives practising independently obtained that $13(43.3 \%)$ midwives did not use SOAP-documenting method and 17 (56.7\%) midwives did perform documentation by using the SOAP method.

Midwifery care documentation can be used as important evidence for evaluating the care provided by midwives, either the midwives had provided care but not documented, or did not provide proper care. Documentation is responsibility and accountability of the midwifery care. This study aimed to find out the factors related to the implementation of the SOAP documentation by midwives in Pekanbaru City in 2016.

\section{Method}

This study was a quantitative observational with cross-sectional study design. ${ }^{12}$ The data were collected from April 11 to July 23, 2016. The population in this study was all 247 midwives at the Maternity Hospital and independent practice midwives in Pekanbaru City amounted where of 191 midwives are taken as sample through systematic random sampling. The dependent variable in this study was the implementation of documentation, while the main independent variable was SOAP documentation.

The data collected were both primary and secondary data. Through interview using questionnaires and observation of the records of the midwife's documentation. The validity and reliability of the questionnaires made were tested on 30 respondents. The validity was tested using significance level 5\% and $\mathrm{r}$ count $>0.4438$ Pearson Product Moment Correlation test. The reliability was tested with Cronbach Alpha value $>0.06$ obtained a questionnaire knowledge $=0.718$ and attitude $=0.910$. Conceptual framework of factors related to the implementation of SOAP documentation included age, education, duration of practice, knowledge, attitude, availability of documentation format, and supervision variable. 
Table 1. Bivariate Analysis of Factors Associated with the Implementation of SOAP Documentation by Midwives in Pekanbaru

\begin{tabular}{|c|c|c|c|c|c|c|c|c|c|}
\hline \multirow{3}{*}{ Variable } & \multirow{3}{*}{ Category } & \multicolumn{4}{|c|}{ Implementation of SOAP Documentation } & & & \multirow{3}{*}{ p Value } & \multirow{3}{*}{ POR $(95 \%$ CI) } \\
\hline & & \multicolumn{2}{|c|}{ Not Corresponding } & \multicolumn{2}{|c|}{ Corresponding } & \multicolumn{2}{|c|}{ Amount } & & \\
\hline & & $\mathbf{n}$ & $\%$ & $\mathbf{n}$ & $\%$ & n & $\%$ & & \\
\hline \multirow[t]{2}{*}{ Knowledge } & Less & 46 & 44.7 & 26 & 29.5 & 72 & 37.7 & 0.046 & $1.924(1.056-3.508)$ \\
\hline & Good & 57 & 55.3 & 62 & 70.5 & 119 & 62.3 & & \\
\hline \multirow[t]{2}{*}{ Attitude } & Negative & 61 & 59.2 & 29 & 33.0 & 90 & 47.1 & 0.001 & $2.955(1.633-5.348)$ \\
\hline & Positive & 42 & 40.8 & 59 & 67.0 & 101 & 52.9 & & \\
\hline \multirow[t]{2}{*}{ SOAP Format } & Unavailable & 58 & 56.3 & 5 & 5.7 & 63 & 33.0 & 0.000 & $21.396(8.006-57.175)$ \\
\hline & Available & 45 & 43.7 & 83 & 94.3 & 128 & 67.0 & & \\
\hline \multirow[t]{2}{*}{ Supervision } & Never & 45 & 43.7 & 7 & 8.0 & 52 & 27.2 & 0.000 & $8.978(3.781-21.317)$ \\
\hline & Ever & 58 & 56.3 & 81 & 92.0 & 139 & 72.8 & & \\
\hline \multirow[t]{2}{*}{ The length of practice } & $>5$ years & 70 & 68.0 & 63 & 71.6 & 133 & 69.6 & 0.700 & $0.842(0.452-1.567)$ \\
\hline & 5 years & 33 & 32.0 & 25 & 28.4 & 58 & 30.4 & & \\
\hline \multirow[t]{2}{*}{ Education level } & Low & 85 & 82.5 & 67 & 76.1 & 152 & 79.6 & 0.362 & $1.480(0.730-2.999)$ \\
\hline & High & 18 & 17.5 & 21 & 23.9 & 39 & 20.4 & & \\
\hline \multirow[t]{2}{*}{ Age } & 34 years & 69 & 67.0 & 59 & 67.0 & 128 & 67.0 & 1.000 & $0.998(0.545-1.827)$ \\
\hline & $<34$ years & 34 & 33.0 & 29 & 33.0 & 63 & 33.0 & & \\
\hline
\end{tabular}

Notes:

$\mathrm{n}=$ Number of Sample, POR $=$ Prevalence Odds Ratio, $\mathrm{CI}=$ Confidence Interval

Table 2. Final Modelling of Multivariate

\begin{tabular}{lrrrr}
\hline \multirow{2}{*}{ Variable } & p Value & POR & \multicolumn{2}{c}{$95 \%$ CI } \\
\cline { 4 - 5 } & & & Lower & Upper \\
\hline Attitude & 0.007 & 2.729 & 1.309 & 5.689 \\
Documentation format & 0.000 & 15.988 & 5.730 & 44.614 \\
Supervision & 0.000 & 6.366 & 2.394 & 16.929 \\
\hline
\end{tabular}

Notes:

$\mathrm{POR}=$ Prevalence Odds Ratio, $\mathrm{CI}=$ Confidence Interval

Computerized data processing and analysis used univariate, bivariate with chi-square test with $95 \%$ Confidence Interval, and multivariate with multiple logistic regression test with the level of significant at 0.05 .

\section{Results}

Implementation of midwifery documentation among midwives at maternity hospital or independent practice midwives in Pekanbaru City in 2016 was only $46.1 \%$. (Table 1). Proportion of midwives with less knowledge of documentation was $54.1 \%$, while those with negative attitude was at $47.7 \%$. There were $33 \%$ with no available SOAP format, $27.2 \%$ with no supervision, $69.6 \%$ with more than five years of practice experience, $79.6 \%$ with low education level, and $67.0 \%$ aged 34 years.

Results of the bivariate analysis between the dependent and the independent variables (Table 1) showed that four of seven independent variables significantly associated with the implementation of the SOAP documentation by the midwife were knowledge, attitude, availability of documentation formats, and supervision. Midwives with less knowledge was associated with the implemen- tation of the SOAP documentation with ( $\mathrm{p}$ value $=0.046$; $\mathrm{OR}=1,924$; CI 95\%=1.056-3.508), as well as midwives with negative attitudes associated with the implementation of the SOAP documentation ( $\mathrm{p}$ value $=0.001$; OR $=$ $2.955 ; 95 \% \mathrm{CI}=1.633-5.348)$, midwives with no available format of SOAP documentation format associated with the implementation of the SOAP documentation ( $\mathrm{p}$ value $=0.000 ; \mathrm{POR}=21.396 ; 95 \% \mathrm{CI}=8.006-57.175)$, and midwives with no supervision associated with the implementation of SOAP ( $\mathrm{p}$ value $=0.000$; $\mathrm{OR}=8.978$; $95 \% \mathrm{CI}=3.781-21.317)$.

The steps of multivariate analysis began from the selection to determine which variables would be entered into the multivariate modeling. In this study, the finalmultivariate modeling significantly related to the implementation of the SOAP documentation was available formats availability, supervision and attitude, and there was no confounding variable.

\section{Discussion}

This study found that the midwife with a negative attitude was 3 times at risk of not implementing SOAP documentation compared to a midwife with a positive attitude $(95 \% \mathrm{CI}=1.309-5.689)$. Attitude is a reaction or response from someone who is still closed to the stimulus or object. This study is in line with the study suggesting a correlation between midwives with negative attitude and midwives with positive attitude towards the implementation of standard obstetric service. ${ }^{14}$

Study by Dike et al., ${ }^{10}$ showed that $71(77.2 \%)$ respondents did not take a documentation immediately after the procedure was performed. The number of respondents using the partograph as documentation at the time 
of delivery were 35 respondents (38\%). Available reports indicate that good quality documentation is an important part of midwifery practice and associated with improved patient care. Respondents mostly pointed to poor documentation practices during labor despite their knowledge. ${ }^{10}$

The documentation of midwifery care provided would protect the midwife from the patients criticism. Midwives must understand the importance of documentation in providing care services, to have a positive attitude and carry out the documentation of midwifery care. Their supervision, monitoring and evaluation as well as the perception of the midwifery association would motivate midwives who act negatively to create documentation by SOAP method.

This study found that the midwife who were not provided with SOAP documentation format had 16 times risk of not implementing SOAP documentation compared to the midwife providing SOAP format (95\% CI: 5.73044.614). Midwifery care provided needs to be recorded, so that midwives can assess the patient's progress. The documentation format consists of components simple, object, access, and protocol. The availability of documentation formats would allow midwives to take a note about the SOAP documentation. This study is in line with a study stating that there was a correlation of availability of facilities with the effectiveness of the implementation of nursing care documentation. 15 The results of study by Martini, ${ }^{16}$ showed a relation between the availability of format documentation and documentation practice at Salatiga Public Hospital (BPRSUD Salatiga).

Midwives who were provided with SOAP format in midwifery care documentation would implement appropriate SOAP documentation. Therefore, it was very important for midwives to be provided with SOAP format in documenting the results of midwifery care. The study also found a midwife who had a SOAP documentation format but did not perform the documentation. There have been provision and the same perception to use the documentation format for Midwifery care with SOAP method by the indonesian Midwives Association. Midwives who had never been supervised were 6 times at risk of not implementing SOAP documentation compared to those who had ever been supervised $(95 \% \mathrm{CI}=2.394$ 16.929).

Supervision is the process spurring members of work units to contribute positively, so that the goal of organization could accomplish. The ability of the supervisor in effectively employing the staff to achieve the employer's goal is important for the success of the supervisor. ${ }^{14}$ This study is in line with that by Mariati, et al., ${ }^{14}$ showing the relation between good supervision and inadequate supervision by the application of maternity care standard. The same results are indicated by the study by Subekti, et al., ${ }^{9}$ which suggested a link between supervision and midwives' performance in midwifery care standard aplication.

Supervision activities such as monitoring the activities of the administration, documentation of midwifery care by the SOAP method. Midwives who have been supervised tend to be better at documenting midwifery care , therefore, supervision should be carried out to improve the quality of service. Stages of supervision can be started from recommendations by the Indonesian Midwives Association branch offices addressed to the association branch office addresed to the association twigs for implementing midwifery practice in the region of the association branches.

The result of study by Putra, ${ }^{17}$ about analysis of the midwives practice in maternity and newborns care, supervision was carried out by coordinator of maternal and child health programs only incidentally carried out at the time of posyandu. The implementation is not carried out spesifically for related programs such as auditing midwifery service standars and perinatal maternal audits. Supervision of the duties and function midwives is needed spesifically and comprehensively. Supervision activities include monitoring the activities of the administration, including the documentation of midwifery care by the SOAP method. Midwives who have been supervised tend to be better at documenting midwifery care, therefore supervision should be carried out to improve the quality of service. Stages of supervision can be started from reccomendations by the Indonesian Midwives Association branch offices addressed to the association twigs for implementing midwifery parctice in the region of the association branches.

\section{Conclusion}

The proportion of midwives cariying out the documentation not in accordance with SOAP is 103 people $(53.9 \%)$. Variables that had a causal relation to the implementation of the SOAP documentation by a midwife in Pekanbaru City in 2016 are the availability of formats, supervision, and attitude. Midwives who did not provide SOAP format were 16 times more likely to carry out the documentation not in accordance with SOAP compared to midwives who do. Midwives who had never been supervised are six times more likely to carry out the documentation not in accordance with SOAP compared to a midwife who ever have. Midwives with a negative attitude are three times more likely to carry out the documentation not in accordance with SOAP compared to midwives with a positive attitude. This study does not have a confounding variable. The independent variables who do not have statistically significant relation to the implementation of the SOAP documentation were knowledge, long period of practice, education, and age. 


\section{Recommendation}

The midwives' association that shelters the midwife practice should socialize the documentation format used for each midwifery care record provided. Periodic supervision is necessary to improve the quality of midwife services through the midwives association. Monthly meeting of midwives can be addressed to hold discussion on midwifery documentation format and obstacles faced in recording midwifery care. This also can improve the attitude of midwives who at first do not want to record their midwifery care due to many reasons, one of ways to encourage them implement the documentation is through the revocation of practice license if they do not do so.

\section{References}

1. Sudarti, Fauziah A. Buku ajar dokumentasi kebidanan. Yogyakarta: Nuha Medika; 2011.

2. Muslihatun WN, Mufdlilah, Setiyawati N. Dokumentasi kebidanan. Yogyakarta: Fitramaya; 2013.

3. Wildan M, Hidayat AAA. Dokumentasi kebidanan. Jakarta: Salemba Medika; 2009.

4. Presiden Republik Indonesia. Undang-Undang RI nomor 36 tahun 2014 tentang tenaga kesehatan [Internet]. Kementerian Hukum dan Hak Asasi Manusia. Jakarta: Kementerian Hukum dan Hak Asasi Manusia; 2014. p. 178. Available from: http://www.pdpersi.co.id/diknakes/data/regulasi/undang_undang/uu362014.pdf

5. Kementerian Kesehatan Republik Indonesia. Keputusan Menteri Kesehatan RI nomor 369 tahun 2007 tentang standar profesi bidan. Jakarta: Kementerian Kesehatan Republik Indonesia; 2007.

6. Kementerian Kesehatan Republik Indonesia. Peraturan Menteri Kesehatan RI Nomor 1464/Menkes/Per/X/2010 tentang izin dan penyelenggaraan praktik bidan [Internet]. Jakarta: Kementerian Kesehatan Republik Indonesia; 2010. p. 1-20. Available from: http://www.kesehatanibu.depkes.go.id/wpcontent/uploads/downloads/2011/12/PMK-1464-Th-2010-ttg-Izin-danPenyelenggaraan-Praktik-Bidan.pdf

7. Kementerian Kesehatan Republik Indonesia. Keputusan Menteri Kesehatan
Republik Indonesia Nomor : 938/Menkes/SK/VIII/2007 tentang standar asuhan kebidanan. Jakarta: Kementerian Kesehatan Republik Indonesia; 2007.

8. Purwanti ED. Kelengkapan dokumentasi asuhan keperawatan dan karakteristiknya pada pasien rawat inap dewasa non kebidanan di Rumah Sakit Haji Jakarta tahun 2012 [skripsi]. Jakarta: Fakultas Kesehatan Masyarakat Universitas Indonesia; 2012.

9. Subekti SS, Widagdo L, Wulan LRK. Faktor-faktor yang mempengaruhi kinerja desa dalam penerapan standar asuhan kebidanan ibu bersalin di Kabupaten Semarang. Jurnal Manajemen Kesehatan Indonesia. 2014; 2(2): $116-22$.

10. Dike FM, Onasoga OA, Njoku E, Dike FM. Documentation in labour among midwives in Madonna university teaching Hospital Elele, Rivers State, Nigeria. International Journal of Reproduction Contraception, Obstetrics and Gynecology. 2015; 4(5): 1404-9.

11. Pengurus Cabang IBI Kota Pekanbaru. Data bidan praktik mandiri di Kota Pekanbaru tahun 2015. Pekanbaru: Pengurus Cabang IBI Kota Pekanbaru; 2015.

12. Lapau B. Metode penelitian kesehatan. Metode ilmiah penulisan skripsi, tesis, dan disertasi. 2nd ed. Jakarta: Yayasan Pustaka Obor Indonesia; 2013.

13. Notoatmodjo S. Promosi kesehatan. Teori dan aplikasi. Jakarta: Rineka Cipta; 2010.

14. Mariati U, Yusefni E, Erwarni. Faktor-faktor yang berhubungan dengan penerapan standar pelayanan kebidanan dalam antenatal care oleh bidan praktik swasta di Kecamatan Padang Selatan Kota Padang. Padang: Report; 2010.

15. Aswar S, Hamsinah S, Kadir A. Faktor yang mempengaruhi efektivitas pelaksanaan pendokumentasian asuhan keperawatan di Instalasi Rawat Inao Bedah Rumah Sakit Umum Daerah Andi Makkasau Parepare. Jurnal Ilmiah Kesehatan Diagnosis. 2014;5(4):460-6.

16. Martini. Hubungan karakteristik perawat, sikap, beban kerja, ketersediaan fasilitas dengan pendokumentasian asuhan keperawatan di Rawat Inap BPRSUD Kota Salatiga [thesis]. Salatiga: Universitas Diponegoro; 2007.

17. Putra A. Analisis praktek bidan pada pelayanan ibu bersalin dan bayi baru lahir. Kesmas: National Public Health Journal [Internet]. 2008; 3(1): 30-8. Available from: http://journal.fkm.ui.ac.id/kesmas/article/view/240 